\title{
해외봉사 프로그램의 혁신적 운영사례
}

목 차

I. 서문

II. 지속가능개발목표란?

1. 새천년개발목표(MDGs)의 성과와 한계

2. 미래 세대를 위한 의제 지속가능개발목표(SDGs)

3. SDGs 달성을 위한 노력

III. 국가별 해외봉사단 프로그램과 다양한 시도

1. 국가별 해외봉사단 프로그램

2. 미국 평화봉사단의 의료협력 파트너십

3. 영국 VSO 기업 협력 프로그램

4. 캐나다 CUSO International의 다양한 시도

$\mathrm{IV}$. 민간 참여 확대-월드프렌즈 NGO봉사단

1. 대한민국 정부 지원 해외봉사단 월드프렌즈코리아(WFK)

2. 민간 단체 협력 프로그램 월드프렌즈 NGO봉사단

3. SDGs 달성을 위한 민간의 역할

V. 한국 기업의 사회적 책임과 봉사단 활동

1. 포스코 글로벌 청년 봉사단 '비욘드'

2. 기업과 시민사회의 협력 '라온아띠'

VI. 결어

참고문헌

1) 이메일 : skyang@ngokcoc.or.kr, 전화: 070-4893-0703, 팩스: 02-2279-1719 


\section{요 약}

효과적인 국제 개발 협력 사업의 수행을 위해서는 정부, 기업, 비정부기구(NonGovernmental Organization, 이하 NGO) 등 사업의 주체가 추구하는 방향성, 전략, 재원, 그리고 사업에 투입되는 인적 요소가 필요하다.

국제 개발 협력 분야에서는 다양한 층위와 그룹의 사람들이 활동을 하는데, 이 중 각국 정부, 민간, 학계에서 운영하는 봉사단 프로그램은 현장의 인적 요소를 채우는데 크게 기여하고 있다.

현재 정부, 민간, 기업을 망라한 국제사회는 지속가능개발목표(Sustainable Development Goals, 이하 SDGs)를 설정하고, 2030년까지 이를 달성하고자 분주히 움직이고 있다.

이 시점, 본 원고에서는 국내외의 다양한 해외봉사 협력 사례를 찾아봄으로써 SDGs 달성을 위한 해외봉사의 역할과 해외봉사의 효과를 확대하는 새로운 파트너십의 방안을 모색하고자 한다.

새천년개발목표와 지속가능개발목표에 대한 이해, 다른 국가의 해외봉사단 프로그램에 대한 개괄과 다양한 시도들, 대한민국 정부-민간의 협력 모델 월드프렌즈 $\mathrm{NGO}$ 봉사단, 그리고 한국 기업의 봉사활동 프로그램과 협력 모델을 파악해 본다.

\section{I. 서 문}

효과적인 국제 개발 협력 사업의 수행을 위해서는 정부, 기업, 비정부기구(Non-Governmental Organization, 이하 NGO) 등 사업의 주체가 추구하는 방향성, 전략, 재원이 필요하다. 그러나 이 모든 요소를 넘어설 만큼 중요한 것이 사업에 투입되는 인적 요소다. 사업의 근간이 되는 가치와 철학에 공감하고, 사업이 요구하는 역량과 전문성을 갖춘 인력이 투입되지 않고서는 설정한 방향과 전략에 맞추어 사업이 움직이기가 어렵기 때문이다.

국제 개발 협력 분야에서는 다양한 층위와 그룹의 사람들이 활동을 하는데, 이 중 각국 정부, 민간, 학계에서 운영하는 봉사단 프로그램은 현장의 인적 요소를 채우는데 크게 기여하고 있다. 봉사단원은 현장의 전문가 그룹과 함께 크고 작은 역할들을 수행하고, 봉사단 프로그램은 향후 이들이 국제 개발 협력 분야로 본격 진출하게 하는 관문(gateway) 역할을 하기도 한다. 해외봉 사 활동은 국제사회가 설정한 발전목표를 달성하는데 있어 핵심 요소이고, 해외봉사 활동이 
대상, 방식, 내용에 있어 효과적으로 수행된다는 것은 국제 개발 협력이 지향하는 목표에 더욱 근접하고 있다는 의미라고도 볼 수 있을 것이다.

정부, 민간, 기업을 망라한 국제사회는 지속가능개발목표(Sustainable Development Goals, 이하 SDGs)를 설정하고, 2030년까지 이를 달성하고자 분주히 움직이고 있다.

이 시점, 본 원고에서는 SDGs 달성을 위한 해외봉사의 역할과 해외봉사의 효과를 확대하는 새로운 파트너십의 방안을 모색하기 위해, 국내외의 다양한 해외봉사 협력 사례를 찾아보고자 한다.

제I장

\section{II. 지속가능개발목표란?}

\section{1. 새천년개발목표(MDGs)의 성과와 한계}

빈곤, 기아, 질병, 환경, 불평등 등의 문제를 해결하고자 하는 전 지구적 움직임은 2000 년 새천년 선언(Millennium Declaration)을 기반으로 한 새천년개발목표(Millennium Development Goals, 이하 MDGs)라는 약속으로 구체화되었다. 국제연합(United Nations, 이하 UN) 회원국들이 세계가 당면한 문제에 대해 공감하고 2015년까지 달성할 개발 협력의 목표와 약속을 공동으로 마련하였다는 측면에서 의미가 큰 MDGs는 개발도상국 극빈자 비율 감소, 최빈국 아동의 교육 기회 확대, 5 세 미만 아동 사망 비율 감소 등의 성과를 보여주었다(UN, 2015).

하지만 MDGs는 UN의 전문가와 관료의 의견을 중심으로 만들어져 시민사회/시민 당사자의 목소리를 제대로 반영하지 못했다는 지적이 있었고, 그 목표 역시 포괄적이지 않아 전 세계가 당면한 문제의 본질을 파악하고 근원적인 해결책을 만들어 가는 측면에서는 한계가 있다는 평가를 받았다. 목표를 설정하는 과정에서 이러한 목표 설정이 왜 필요한 것인지, 지구촌의 문제를 해결해나가기 위해 왜 전 세계가 힘을 합치고 공동의 노력을 펼쳐나가야 하는 것인지에 대한 근본적인 공감대 형성의 기회가 필요하다는 것, $\mathrm{MDGs}$ 의 8가지 목표로는 점점 더 심각해 지고 복잡해지는 지구촌의 문제에 대해 효과적인 대응과 해답을 제시하기 어렵다는 인식이 생겨난 것이다. 이런 반성을 토대로 MDGs의 기한인 2015년을 넘어 2016년 이후 세계가 함께 달성해 나갈 새로운 목표를, 새로운 방식으로 만들자는 목소리가 힘을 얻게 되었다. 이로써 만들어 진 것이 'SDGs'이다. 


\section{2. 미래 세대를 위한 의제 지속가능개발목표(SDGs)}

1987년 '세계환경개발위원회(World Commission on Environment and Development, $\mathrm{WCED}$ )'에서 발표한 『우리 공동의 미래(Our Common Future)』라는 보고서에 등장하여 논의되기 시작한 '지속가능한 발전'이라는 개념은 '미래 세대가 그들의 필요를 충족시킬 능력을 저해하지 않으면서 현재 세대의 필요를 충족시키는 발전(development that meets the needs of the present without compromising the ability of future generations to meet their own needs) (UN, 1987)'으로 정의된다.

환경 또는 경제 특정 분야의 지속가능 발전을 의미하는 것을 넘어, 전 세계적으로 진행되고 있는 경제·사회 양극화, 사회적 불평등 심화, 지구환경의 파괴 등 인류의 지속가능한 발전을 위협하는 요인들을 동시적으로 완화해 나가기 위한 의제들로 구성되어 있다.

2015년 9월 UN 총회에서 합의된 SDGs는 2016-2030년 동안 모든 나라가 공동으로 추진해 나갈 목표 17 개를 담고 있다.

〈그림 1〉 지속가능개발목표 (SDGs)

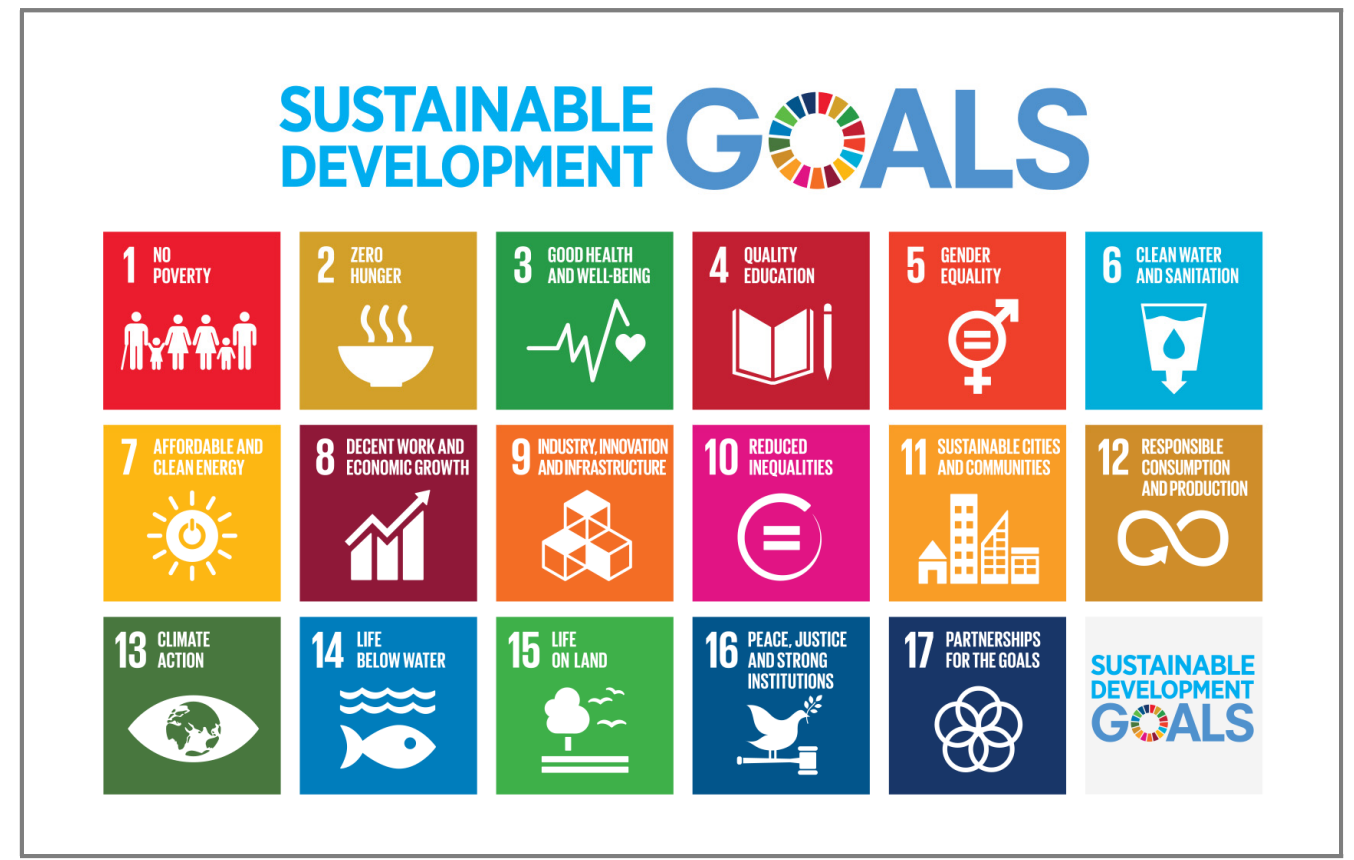

출처: Sustainable Development Knowledge Platform 홈페이지(https://sustainabledevelopment.un.org) (접속일: 2017.04.16.) 
$\mathrm{SDGs} 17$ 개 목표는 사회 발전, 경제성장, 환경보전 3가지 축으로 이루어진다. 목표 1-6은 사회 발전 영역의 목표로 빈곤 퇴치, 불평등 해소, 인간 존엄성 회복을 그 내용으로 한다. 목표 8-11은 경제성장을 달성하기 위한 목표이다. 양질의 일자리, 경제 환경 구축, 지속가능 한 성장 동력 마련이 핵심이다. 목표 7, 12-15는 환경보전을 위한 목표이다. 기후변화, 자연재 해, 자원고갈에 대한 대응이다. 나머지 16,17 은 $1-15$ 의 목표를 달성하기 위한 조건과 방법을 담고 있다.

SDGs를 5가지 키워드 - 사람(People), 번영(Prosperity), 지구(Planet), 평화(Peace), 파트너십

(Partnership) - 5P로 구조화할 수도 있다.

MDGs와의 차이점을 비교해 본다면, 달성 주제/분야 면에서 MDGs가 빈곤·의료 등 사회 분야 중심이었다면 SDGs는 경제성장, 기후변화 등 경제·사회·환경을 통합적으로 포괄한다는 점, 참여주체 면에서 MDGs가 정부 중심이었다면 SDGs는 정부뿐만 아니라 시민사회, 민간기 업 등 모든 이해관계자의 참여를 기반으로 한다는 점이다.

\section{SDGs 달성을 위한 노력}

$\mathrm{SDGs}$ 달성을 위한 각 국가, 주체의 노력은 다양한데, 빈곤과 기아종식, 건강, 보건/의료, 교육, 식수, 에너지, 지역개발, 사회 인프라, 주거, 환경 등 다양한 분야에서 정부 차원의 개발 협력 사업이 이루어지고 있고, 기업 차원의 투자/협력과 개발 협력의 현장으로 더 가까이 들어가 는 $\mathrm{NGO}$ 의 사업 역시 활발하게 펼쳐지고 있다. 그리고 이러한 정부, 기업, $\mathrm{NGO}$ 들의 활동에 필요한 수많은 요소들 중 중요한 것이 방향성, 전략, 재원, 그리고 인적 요소다. 이중 인적 요소는 다양한 층위, 그룹으로 분류할 수 있는데, 국제 개발 협력 분야의 여러 전문가 그룹 - 교육, 공공행정, 농림수산, 보건, 산업에너지 분야, 세부적으로는 유아/초등/청소년 교육, 직업 교육, 예체능 교육, 사회복지, 개발 정책, 농업, 임업, 축산, 지역개발, 모자보건, 간호, 치위생, 물리치료, 식수위생, 건축, 설비 등의 전문 인력이 한 역할을 담당하고 있다. 그리고 수원국 현지의 인적 기반 역시 효과적인 개발 협력 사업을 위해 필수적인 부분이다. 이에 더해 인적 요소의 또 다른 중요한 축을 이루는 것이 해외봉사단원이다.

해외봉사단은 프로그램의 성격에 따라 전문적인 영역에서 자신의 역랑을 발휘하기도 하고, 때로는 전문가 그룹/봉사단이 수행하는 활동을 지원하는 역할을 하기도 한다. 어떤 형태의 프로그램이든 봉사단원은 자신이 활동하는 현지 기관의 개발 협력 사업에 크고 작은 기여를 하고 있고, 이러한 노력들이 축적되어 작은 변화가 만들어진다. 그리고 이러한 변화가 SDGs의 
17 개 목표를 달성하는데 있어, 작지만 나아가 커지는 소중한 하나하나의 디딤돌이 되는 것이다.

각각의 봉사단 프로그램은 그 자체로도 SDGs 달성에 기여하는 바가 크지만, 최근에는 다양 한 파트너십을 통해 새로운 가능성을 열어 보이고 있다. 이에 해외봉사 프로그램의 혁신적 운영 사례, 파트너십 사례를 찾아보고자 한다.

\section{III. 국가별 해외봉사단 프로그램과 다양한 시도}

\section{1. 국가별 해외봉사단 프로그램}

세계 각국에서 정부 차원의 해외봉사단을 파견하고 있는데, 미국과 일본이 대표적이다. 미국 평화봉사단(Peace Corps)은 2015년 9월 말 기준 63개 국가에서 6,919명의 봉사단원이 활동하 고 있고 이를 위해 미국 정부는 연간 379백만 불이 넘는 예산을 지원한다(Peace Corps, 2015). 1961년 이래 누적 22만 명이 넘는 봉사단원이 전 세계로 파견되었다.

일본 국제협력기구(Japan International Cooperation Agency, JICA)가 운영하는 봉사단 (Japan Overseas Cooperation Volunteers, JOCVs)은 2015년 8월 누적 기준 96개 국가, 48,000명이 넘는 봉사단원이 파견되었다.2)

이외 영국 해외봉사단(Voluntary Service Overseas, 이하 VSO)도 2015-2016년 기준 24개 국가에서 전문 봉사단 및 ICS(International Citizen Service)라고 하는 청년 봉사단 프로그램을 운영하고 있다. 영국 국제개발부(Department for International Development, 이하 $\mathrm{DFID}$ )가 재정의 $27 \%$ 를, 기타 영국 정부 지원이 $51 \%$ 로 예산의 $80 \%$ 를 정도를 정부가 지원한다(VSO, 2016:27).

\section{2. 미국 평화봉사단의 의료협력 파트너십}

각국 봉사단은 이미 여러 가지 봉사단 프로그램을 운영하는 한편, 오랜 기간 축적된 경험을 기반으로 새로운 시도들을 선보이기도 한다.

미국 평화봉사단은 2년간의 일반 봉사단 프로그램(Peace Corps Volunteer) 외에, 기간은

2) JICA Volunteer Program을 참조하기 바란다. (http://www.jica.go.jp/english/our_work/types_of_assistance/ citizen/volunteers.html) (접속일 : 2017.04.16) 
짧으나 좀 더 전문적인 기술을 보유한 이들을 3-12개월 동안 파견하는 전문 봉사단 프로그램 (Peace Corps Response), 그리고 열악한 의료 상황에 처해있는 아프리카 5개국(라이베리아, 말라위, 스와질란드, 탄자니아, 우간다)에 의료진을 파견해 현지 의료진 교육/역량 강화를 지원 하는 글로벌 의료협력 파트너십(Global Health Service Partnership, 이하 GHSP)도 운영하 고 있다.

이중 2012년부터 시작된 GHSP는 미국 평화봉사단과 에이즈 구호를 위한 대통령 긴급 계획 (U.S. President's Emergency Plan for AIDS Relief, PEPFAR)과 NGO인 시드글로벌헬 스(Seed Global Health)가 협력하여 추진하는 프로그램인데, 단순히 의료진을 파견하여 의료 활동을 하는 것에 그치지 않고, 의료 활동을 하는 동시에 의사, 간호사 등 현지 의료 인력을 양성하기 위한 교육 활동을 함께 수행한다. 첫 활동 연도인 2012-2013년에는 30명의 의사와 간호사가 말라위, 탄자니아, 우간다의 11개 교육 기관에 배치되었고, 2014-2015년에는 42명의 의료 교육진이 동일한 국가의 13 개 기관에 파견되어 활동하였다. 3 )

미국 평화봉사단의 GHSP는 일반적인 봉사단 활동을 넘어서서 더 전문적이고, 더 정교하게 설계된 활동을 수행한다는 점이 눈에 띈다. 의료 분야가 특별히 취약한 국가를 대상으로, 전문 의료진들이 전문 기관들과 협력하여 더 세밀하게 활동 계획을 수립하고, 의료 및 교육 서비스를 통해 해당 국가의 의료적 기반을 다져주는 프로그램이라 더욱 효과적인 서비스이다. 외국에서 파견된 의료진들이 활동을 마쳐도, 현지의 역량으로 장기적이고 계속적인 의료 서비스가 이루어 질 수 있도록 하는 것, 지속가능한 의료, 지속가능한 삶, 지속가능한 발전을 가능케 하는 모델이 라 평가할 수 있다. 더구나 봉사단 사업 수행기관과 해당 분야의 전문 기관, 전문 인력, 정부의 정책이 함께 어우러지는 모범적인 파트너십의 형태라는 점에서 더욱 의미가 있다.

\section{3. 영국 VSO 기업 협력 프로그램}

영국 $\mathrm{VSO}$ 는 교육, 건강, 생계수단, 그리고 참여와 거버넌스 4 가지 주제 영역을 정하여 해당 분야 경험이 있는 봉사단원을 파견하며, 해당 영역별로 설정된 수혜자 목표를 기반으로 성과를 측정하고 평가한다. 이외 아시아, 아프리카, 중남미 국가에서 10-12주간 활동하는 청년 봉사단 프로그램 ICS (International Citizen Service)를 운영하는데, 10 개의 개발 협력 기관과의 파트너십으로 운용되며, 2012년 프로그램이 시작된 이래 2016년 2월 파견인원 2만 명을 돌파하 였다(VSO, 2016, p.16).

3) 자세한 사항은 시드글로벌헬스 홈페이지를 참조하기 바란다. (http://seedglobalhealth.org/about) (접속일: 2017. 04.16.) 
영국 VSO에서 눈에 띄는 것은 기업과의 협력 프로그램이다. 2015년 UN 총회에서 SDGs 설정 시, SDGs를 달성하는데 있어 민간이 주요 파트너임이 공식적으로 인정되었다고 볼 수 있는데, 2015년 7월 VSO는 '지식 교류(knowledge exchange)'를 대표적인 기업 연계 봉사단 프로그램으로 선보였다. 개발 협력 프로그램에 있어 민간 영역 노하우의 필요성이 점진적으로 확대되는 상황 속에서 영국 $\mathrm{DFID}$ 가 초기 자금을 지원하여 시작된 프로그램이다. 유명 글로벌 기업들이 함께 하는 VSO '지식 교류' 프로그램을 통해 지역사회는 새로운 기술과 역량을 획득 하고, 삶을 개선하며, 민간 영역에 대한 이해를 높일 수 있다. 봉사단원으로 참가하는 직원들은 리더십 역량을 키울 수 있는데, 예를 들면 혁신, 유연성, 전략적 사고, 팀 리딩 기술을 향상시키고, 새로운 상품과 서비스에 대한 아이디어를 얻을 수 있다. 또 새로운 시장에 대한 정보와 지식, 타문화에 대한 인지도도 높일 수 있다. 기업은 직원에게 보상할 기회를 가지는 동시에 기업의 사회적 책임(Corporate Social Responsibility, CSR) 활동에 직원을 참여시키는 기회를 가지 고, 직원의 재능을 발견 또는 항상시킬 수 있고, 신흥 시장에 대한 이해를 높일 수 있다. 신상품 개발, 글로벌 공급망에 대한 이해 증진도 기업이 누릴 수 있는 혜택이다.4)

2015-2016년 VSO '지식 교류'는 NTT Data와 Citi가 새로운 파트너로 참가해 가나와 케냐에서 활동하였고, 액센츄어(Accenture), IBM, 신젠타(Syngenta), 란스타드(Randstad), 셸(Shell) 등 쟁쟁한 기업들이 봉사단 활동과 자금 지원을 동시에 수행하였다(VSO, 2016: 19).

사례를 몇 가지 들여다보면, Citi는 우간다, 헝가리, 프랑스, 스위스, 이스라엘, 영국 등지에서 12 명의 기업 투자금융 직원들이 파견되어 활동하였는데, 사업을 하고자 하는 주민들이 사업 전략과 수익 증대방안을 찾을 수 있도록 멘토 역할을 수행했다.

$\mathrm{IBM}$ 은 CSC (Corporate Service Corp)라는 자체 프로그램을 운영하고 있는데, 연간 500 명 규모의 직원을 파견하여 건강, 교육, 사회 및 경제 개발 과제를 수행하도록 하고 있다. 직원들 은 10-15명씩 팀을 이뤄 지역 정부, NGO, 대학, 소규모 사업을 지원하는데, 이들의 역할은 정부기관의 기술 역량을 업그레이드 하는 것에서부터 지역의 빈곤 감소 활동에까지 이른다.

글로벌 농업기업 신젠타는 방글라데시에서 주민들의 수입 증대와 식량 확보를 지원하기도 하였다. 기후변화, 제한된 농지, 시장 접근성 문제로 소규모 농민들은 수입은 고사하고 먹을 음식을 생산해 내는 것도 힘든 상황이 많다. 'Growing Together' 프로그램을 통해 신젠타 직원들은 현지의 Rural Development and Relief Services와 협력하여 농민들의 자립을 돕는 다. 15 명으로 구성된 2 개의 팀이 4 주의 기간 동안 파견되어 활동한다.

4) 자세한 사항은 VSO 홈페이지를 참조하기 바란다. (https://www.vsointernational.org/volunteering/internationalcorporate-volunteering) (접속일: 2017.04.16.) 


\section{4. 캐나다 CUSO International의 다양한 시도}

캐나다의 봉사단 프로그램을 운영하는 CUSO (Canadian University Services Oversea) International(이하 CUSO)은 전문 역량을 가진 봉사단, 협력 파트너십, 그리고 기부자들의 노력을 통해 빈곤 및 불평등을 감소하고자 하는 단체이다. 더 정의롭고 지속가능한 세상을 위해 CUSO는 커뮤니티, 건강, 생계수단을 주요 영역으로 하여 봉사단을 파견한다. CUSO의 봉사단 프로그램은 매우 다양한데, International Volunteering, Diaspora Volunteering, E-봉사단(E-Volunteering), Corporate Volunteering, Volunteer in Canada, SouthSouth Volunteering, Customized Services, International Youth Internship Program, Community Selector Volunteers, Public Outreach Volunteers가 있다.5)

〈표 1〉CUSO International 봉사단 프로그램 종류

\begin{tabular}{|c|c|}
\hline 구분 & 내용 \\
\hline $\begin{array}{l}\text { International } \\
\text { Volunteering }\end{array}$ & $\begin{array}{l}\text { 아프리카, 아시아, 중남미, 카리브 지역에 파견되어 경험과 노하우를 나누는 } \\
\text { 전문 봉사단 프로그램. 활동기간은 6-24개월. 공동체, 건강, 생계 관련 프로 } \\
\text { 젝트에서 세계 동료들과 함께 활동함. }\end{array}$ \\
\hline $\begin{array}{c}\text { Diaspora } \\
\text { Volunteering }\end{array}$ & $\begin{array}{l}\text { 국가, 지역, 문화, 언어 등 다양한 지리적 - 문화적 이슈에 대한 이해와 전문 } \\
\text { 지식을 토대로 활동하는 봉사단. 전문적 네트워크를 확장하고, 국가 간 사업 } \\
\text { 적 협력관계를 강화하며, 해외에서의 경험을 공유함. } 10 \text { 년 이상 운영 }\end{array}$ \\
\hline $\begin{array}{c}\mathrm{E}-\text { 봉사단 } \\
\text { (E-Volunteering) }\end{array}$ & $\begin{array}{l}\text { 해외에 나가지 않고 봉사활동을 하고자 하는 이들을 위한 프로그램 } \\
\text { 이메일, 스카이프 또는 다른 웹 기반 기술을 통해 활동을 수행함 } \\
\text { - Peer-to-peer - 이메일을 통해 해외와 소통 및 업무 수행 } \\
\text { - E-mentoring - 스카이프와 같은 온라인 툴을 이용하여 해외에 있는 수혜 } \\
\text { 자와 기술 및 경험을 나누고, 역량 강화에 기여 } \\
\text { - Task-based technical assistance - 웹 사이트, 사업 계획, 리서치 } \\
\quad \text { 프로젝트, 마케팅, 캠페인 등의 봉사단 업무를 원격 수행 }\end{array}$ \\
\hline $\begin{array}{c}\text { Corporate } \\
\text { Volunteering }\end{array}$ & $\begin{array}{l}\text { 다양한 직업 및 연구 경험을 토대로 축적된 전문성을 필요로 하는 해외 기업 } \\
\text { 및 기관에서 봉사활동을 하는 프로그램 } \\
\text { 봉사단원은 글로벌 이슈에 대한 이해, 문화 간 전문성, 문제 해결 능력 등을 } \\
\text { 습득할 수 있고, 기업 또는 기관은 봉사단원이 귀국 후 업무/연구 복귀 시 } \\
\text { 봉사활동을 통해 쌓은 단원의 새로운 전문성 및 기술을 활용할 수 있음. } \\
\text { 기업 봉사활동은 직원에게 메리트가 될 뿐만 아니라 직원의 역량을 키울 } \\
\text { 수 있는 프로그램임 } \\
\text { 사업 관리자, } M \& E \text { 자문, 재정 자문, 전략기획가, 마이크로파이낸스 자문, } \\
\text { 프로젝트 관리자, IT 전문가, 마케팅 등의 영역에서 활동 }\end{array}$ \\
\hline
\end{tabular}

5) 자세한 사항은 CUSO International 홈페이지를 참조하기 바란다. (http://www.cusointernational.org/volunteer/ types-of-volunteers) (접속일: 2017.04.16.) 


\begin{tabular}{|c|c|}
\hline 구분 & 내용 \\
\hline Volunteer in Canada & 해외 파견이 아니라 캐나다 국내에서 수행하는 봉사활동 프로그램 \\
\hline $\begin{array}{l}\text { South-South } \\
\text { Volunteering }\end{array}$ & $\begin{array}{l}\text { 중남미 또는 카리브 지역에 거주하는 전문가가 자신의 국가, 지역이 아닌 } \\
\text { 중남미/카리브 지역에서 봉사활동을 할 수 있게 하는 프로그램. 지역 사회, } \\
\text { 문화, 언어에 대한 이해를 증진시킴. 지난 } 20 \text { 년간 } 500 \text { 명에 이르는 봉사단원 } \\
\text { 을 파견함 }\end{array}$ \\
\hline Customized Services & $\begin{array}{l}\text { 선발, 교육, 활동 등을 기관이 원하는 형태로 세팅하는 맞춤형 봉사단 프로그 } \\
\text { 램. } 50 \text { 년 이상 봉사단 프로그램을 운영한 노하우를 기반으로 기업, 공공기관, } \\
\text { 비영리기관 등이 원하는 양질의 봉사단 프로그램 운영 가능. 직원 대상 봉사 } \\
\text { 활동 프로그램, 사업 해외 진출을 위한 프로그램 등 }\end{array}$ \\
\hline $\begin{array}{l}\text { International Youth } \\
\text { Internship Program }\end{array}$ & $\begin{array}{l}\text { 캐나다 정부 지원으로 } 2 \text { 년 동안 } 35 \text { 명의 캐나다 청년을 } 5 \text { 개 국가의 파트너와 } \\
\text { 연결. } 2017 \text { 년 3월 } 31 \text { 일 종료 }\end{array}$ \\
\hline $\begin{array}{l}\text { Community Selector } \\
\text { Volunteers }\end{array}$ & $\begin{array}{l}\text { 봉사단 선발 시 해당 지원자의 기초적인 해외 활동 역량을 평가하는 지역 } \\
\text { 단계 선발 수행 봉사단 }\end{array}$ \\
\hline $\begin{array}{l}\text { Public Outreach } \\
\text { Volunteers }\end{array}$ & $\begin{array}{l}\text { 자신의 지역사회, 공동체 내에서 국제 개발 수행. 봉사단원 선발, 교육, 이벤 } \\
\text { 트 기획 등 }\end{array}$ \\
\hline
\end{tabular}

출처: CUSO International 홈페이지 Type of Volunteers (http://www.cusointernational.org/ volunteer/ types-of-volunteers) (접속일: 2017.04.16.)

이 중 $\mathrm{E}$-봉사단은 기술의 발달로 봉사활동의 형태가 바뀔 수 있음을 보여주는 혁신적인 사례이다. 2012년 시작된 이 프로그램은 현장으로 파견되지 않고도 자신의 사무실, 집에서 자신의 전문적인 역량을 발휘하여 개발 프로그램의 수행 및 현지의 변화에 기여할 수 있는 프로그램이다. 멘토링, 웹 사이트 개발, 소셜 미디어, 제안서 작성, 번역, 펀딩 등 다양한 분야에 서 활용이 가능하다. CUSO는 아프리카, 아시아, 중남미, 카리브 연안의 20개 국가에서 빈곤층 및 소외 계층의 공동체가 경제적, 사회적으로 삶의 환경을 개선할 수 있도록 2015년 4월 기준 82 명의 $\mathrm{E}-$ 봉사단을 운영하였다.

눈에 띄는 사례로는, 20 년 경력의 무역 전문가 닉 브렌트(Nick Brent)가 프로젝트 관리 및 국제 사업개발 분야에서 캐나다의 중소기업 지원은 물론, 중남미, 아프리카, 중동의 스타트업 을 지원한 것을 들 수 있다. 벨리즈(Belize) 카카오 농부의 삶을 개선하기 위해 설립된 스타트업 마야 마운틴 카카오(Maya Mountain Cacao) 팀을 구성해 협력한 것이 그것이다. 농부들에게 돌아가는 수익을 확대하여 생활수준, 소득 증대는 물론 지역 내 학교 출석률이 높아지는 결과를 얻었다.

마야 마운틴 카카오 팀의 $\mathrm{E}$-봉사단원은 다양한 전문가로 구성되었는데, 멕시코 출신의 브랜 딩 전문가, 워싱턴의 분석가 등이 그들이다. 
마야 마운틴 카카오는 이제 한 국가에서만 활동하는 소형 벤처 스타트업이 아니라, 여러 국가에서 다양한 파트너십을 통해 유사한 성공사례를 만들어 나가고 있다.

\section{IV. 민간 참여 확대 - 월드프렌즈 NGO봉사단}

\section{1. 대한민국 정부 지원 해외봉사단 월드프렌즈코리아(WFK)}

2009년 대한민국 정부 지원 해외봉사단 프로그램을 통합하여 탄생한 월드프렌즈코리아

(World Friends Korea, WFK)는 다양한 기관과 협력하여 다양한 기간, 형태의 봉사단을 세계 곳곳에 파견하고 있다. 월드프렌즈코리아라는 이름으로 2015년 기준 연간 4,814명 파견, 1990 년 첫 파견 이래 누적 인원이 55,763 명에 이르렀으며 파견 국가는 96 개국에 이른다 (KOICA, 2016).

〈표 2〉 월드프렌즈코리아(WFK) 수행기관 및 프로그램

\begin{tabular}{|c|c|c|c|c|}
\hline 소관부처 & 수행기관 & 봉사단명 & 파견기간 & 파견대상 \\
\hline \multirow{5}{*}{ 외교부 } & \multirow{5}{*}{ KOICA } & 월드프렌즈 코이카봉사단 & 2년 & 20세 이상 \\
\hline & & 월드프렌즈 드림봉사단 & 1년 & $\begin{array}{c}\text { 마이스터고, } \\
\text { 특성화고 졸업반 }\end{array}$ \\
\hline & & 월드프렌즈 청년 중기봉사단 & 6개월 & 대학생 \\
\hline & & 월드프렌즈 NGO봉사단 & 1년 & 18세 이상 \\
\hline & & 새마을 리더 봉사단 & 1년 & 20세 이상 \\
\hline 산업통상자원부 & 정보통신산업진흥원 & 월드프렌즈 자문단 & 1년 & 퇴직(예정)자 \\
\hline \multirow{2}{*}{ 교육부 } & 한국대학사회봉사협의회 & \multirow{2}{*}{ 월드프렌즈 청년봉사단 } & \multirow{2}{*}{ 2 3주 } & \multirow{2}{*}{ 청년/대학생 } \\
\hline & (사)태평양아시아협회 & & & \\
\hline \multirow{2}{*}{ 미래창조과학부 } & 한국연구재단 & 월드프렌즈 과학기술지원단 & 1년 & 이공계 학위 \\
\hline & 한국정보화진흥원 & 월드프렌즈 IT봉사단 & 4 12주 & 청년 \\
\hline 문화체육관광부 & 세계태권도평화봉사재단 & $\begin{array}{l}\text { 월드프렌즈 태권도 } \\
\text { 평화봉사단 }\end{array}$ & 1개월 1년 & 청년 \\
\hline
\end{tabular}

출처: 한국국제협력단, “월드프렌즈코리아 브로셔" 프로그램 개요 
각각의 수행기관은 정보통신, 대학생 봉사활동, 연구 활동, 체육 등 기관의 전문영역에 맞는 특성화된 봉사단 프로그램을 운영하고 있다.

\section{2. 민간 단체 협력 프로그램 월드프렌즈 NGO봉사단}

이 중 월드프렌즈 $\mathrm{NGO}$ 봉사단은 시민사회, 민간 차원의 참여를 최대화한 것으로, 국제 개발 협력 NGO와 한국 국제협력단(Korea International Cooperation Agency, 이하 KOICA)의 협력을 통해 국제개발협력민간협의회(Korea NGO Council for Overseas Development Cooperation, 이하 $\mathrm{KCOC}$ )가 운영하는 민간 봉사단 파견 프로그램이다.

세계 각국의 봉사단 프로그램과 WFK 봉사단을 운영하는 여러 기관들이 봉사단 선발부터 파견, 관리에 이르기까지 일괄적으로 수행하는 것과 달리 월드프렌즈 NGO봉사단은 KOICA$\mathrm{KCOC}$-파견단체-현지사업장의 역할이 각각 나뉘어져 있고, 파견단체별 배분 인원은 외부전문 가 및 $\mathrm{KCOC}$ 의 심사를 거쳐 결정되나 현지 사업장에서 필요로 하는 최적의 인력을 확보할 수 있도록 배분된 인원 내 봉사단원 선발에 대한 권한은 파견단체에게 주어져 있다.

$\mathrm{KOICA}$ 의 재정 지원을 통해 진행되며, 협력 $\mathrm{NGO}$, 즉 파견단체 본부는 단체별 사업계획 및 모집·선발부터 출국 후 단원의 활동 지원·관리 및 사업보고를 담당하고, 파견 단체 현지 사업장은 단원의 현지 업무와 활동을 관리하며, $\mathrm{KCOC}$ 는 이에 필요한 월드프렌즈 $\mathrm{NGO}$ 봉사단 사업의 종합 계획, 단체·단원 심사 및 교육, 모니터링, 평가, 사후관리 등을 수행한다.

월드프렌즈 $\mathrm{NGO}$ 봉사단의 특징은 국제 개발 협력 $\mathrm{NGO}$ 의 사업장으로 단원을 파견함으로써 세계 곳곳의 오지로 진출한 한국 $\mathrm{NGO}$ 의 활동을 촉진하고, 현지 활동을 위한 인적 지원, 나아가 길게는 3년간의 활동을 통해 봉사단원이 개발 협력에 대해 더욱 깊이 이해할 수 있도록 한다는 것이다. 이로써 봉사단원은 해당 국가, 지역, 분야의 전문가로 성장할 수 있고, 이를 통해 NGO 의 인적 기반을 더욱 강화할 수 있게 되는 것이다.

특히 NGO의 특성상 현지 지역과 주민의 생활 속으로 더욱 친밀하게 들어가 사업을 수행하는 바, NGO 활동이 길지만 천천히 현지에 기여하고 현지의 변화를 가져올 수 있고, 봉사단원이 활동을 통해 얻게 되는 경험과 지식은 그 어떤 봉사단 프로그램보다 실제적이고 농축되어 있다 고 말할 수 있다.

파견국 현지와의 협력을 통해 단원 파견지를 확보하는 측면이 있어 기본적으로는 그 어떤 봉사단 프로그램이든 파트너십이 중요한 요소로 작용하고 있는데, 월드프렌즈 NGO봉사단은 
단원 파견지를 확보하는 차원을 넘어, 협력 $\mathrm{NGO}$, 즉 파견단체가 더 주도적으로 사업을 수행하 도록 하는 협력관계에 기반을 두고 있어 파트너십의 의미와 중요성이 더욱 크다. $\mathrm{KCOC}$ 가 선발해 보내주는 단원을 기다리는 것이 아니라 파견단체가 현지 사업을 수행하면서 사업 수행에 필요한 인력 계획을 세우고, 이중 봉사단으로 수행할 업무를 정하며, 인원/역할 등 봉사단 활동 계획을 수립한 후 단원 선발과 파견, 일상적인 관리를 책임지고 수행한다.

봉사단 활동의 큰 목적과 방향성은 $\mathrm{KCOC}$ 가 $\mathrm{KOICA}$ 와의 협의를 통해 설정하고 총괄 관리 역시 $\mathrm{KCOC}$ 가 수행하나, 단원을 선발하는 것은 파견단체가 해당 단체의 가치, 특성, 활동 내용

을 고려하여 직접 수행하고, 현장에서의 사업 내용 및 단원활동 내용에 대한 관리 역시 $\mathrm{KCOC}$ 와 공유는 하되 파견단체가 주도적으로 실시한다.

이로써 봉사단원은 $\mathrm{KCOC}$ 의 이름으로 현지에 파견된다기보다 파견단체의 소속으로 주체적 으로 활동하고 경험하는 존재가 되는 것이다.

〈그림 2〉 월드프렌즈 NGO봉사단 사업운영 체계

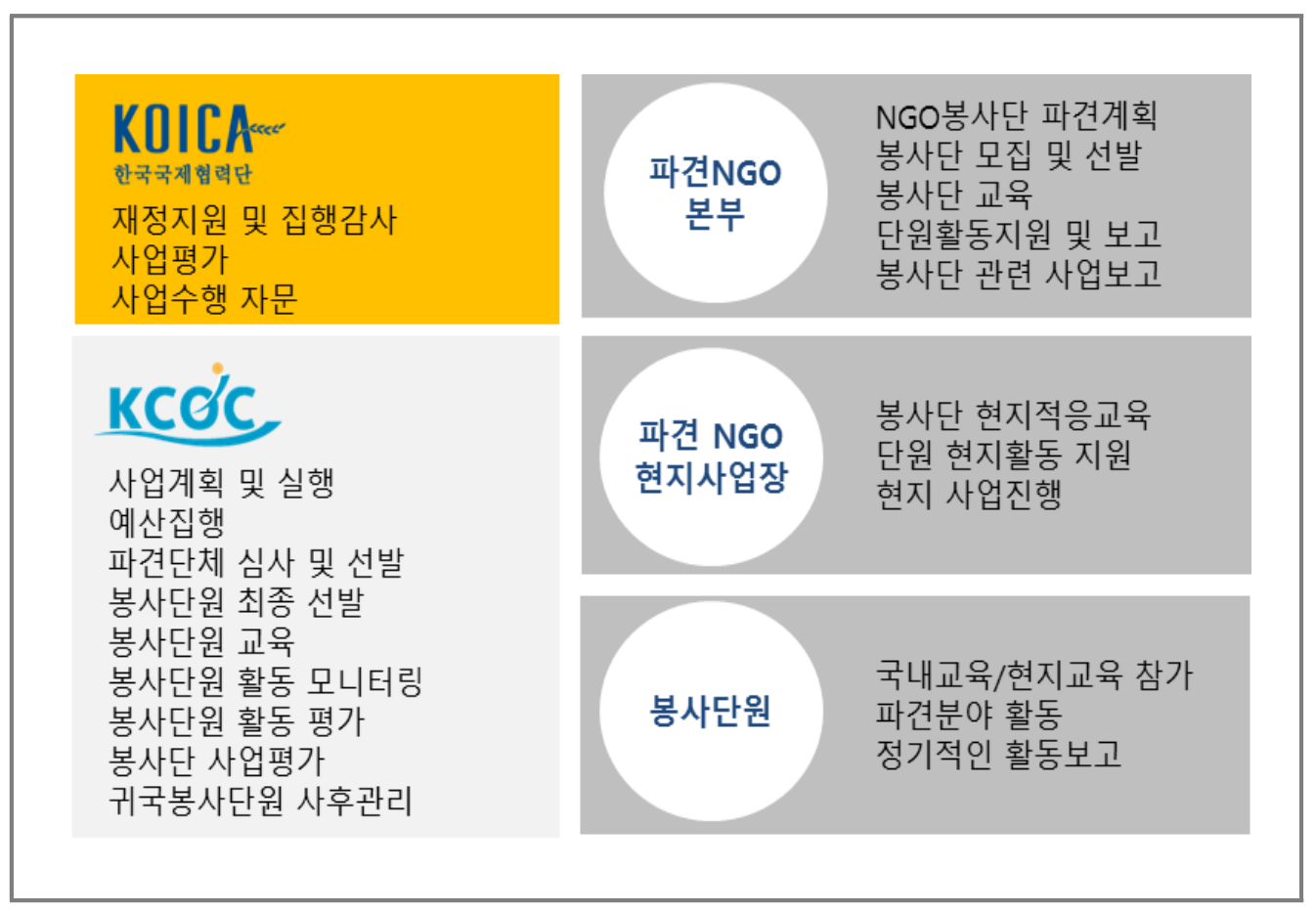

출처: 국제개발협력민간협의회, “월드프렌즈 NGO봉사단 브로셔" 
〈표 3〉 월드프렌즈 NGO봉사단 세부 프로그램 (2017년 기준)

\begin{tabular}{|c|c|c|c|}
\hline 구분 & 특징 & 파견기간 & 인원 \\
\hline $\begin{array}{l}\text { 일반 } \\
\text { 봉사단 }\end{array}$ & $\begin{array}{l}\text { 협력대상국의 경제 · 사회 발전과 우호협력 증진, 시민사회 개발 } \\
\text { 효과성 증진, 그리고 봉사단원의 성장과 인적자원 개발을 목적으 } \\
\text { 로 다양한 분야에 파견하는 봉사단 프로그램 }\end{array}$ & $\begin{array}{c}\text { 1년 } \\
\text { (2월 ) }\end{array}$ & 300명 \\
\hline $\begin{array}{l}\text { 프로그램 } \\
\text { 매니저 } \\
\text { (PM) }\end{array}$ & $\begin{array}{l}\text { 국제 개발 협력 사업 효과성을 제고하고, 사업수행역량 강화, 해 } \\
\text { 외개발사업의 전반적 질과 전문성을 높이고자 파견하는 해당 분 } \\
\text { 야 경력자 대상 봉사단 프로그램 } \\
\text { (1) 프로그램 관리자 : 개별 사업 발굴, 수행 및 평가 } \\
\text { (2) 분야 전문가 : 보건, 의료, 농림, 에너지 등 전문분야 }\end{array}$ & $\begin{array}{c}\text { 1년 } \\
\text { (2월 ) }\end{array}$ & 15명 \\
\hline $\begin{array}{c}\text { 코디네이터 } \\
\text { (코디) }\end{array}$ & $\begin{array}{l}\text { 파견국 현지의 개발 협력 네트워크를 강화하고, 현지 } \mathrm{NGO} \text { 의 사 } \\
\text { 업 수행능력 증대, 실무역량 강화, 봉사단 관리 지원, 활동 시너지 } \\
\text { 확대 등을 위해 파견하는 국가 코디네이터 프로그램 }\end{array}$ & $\begin{array}{c}\text { 1년 } \\
\text { (2월 ) }\end{array}$ & 10명 \\
\hline $\begin{array}{c}\text { 꿈꾸는 } \\
\text { 청년봉사단 }\end{array}$ & $\begin{array}{l}\text { 청소년에게 새로운 경험의 장과 타문화 이해의 기회를 제공하여 } \\
\text { 삶에 대한 성찰, 진로 탐색을 가능하게 하고, 지구촌 문제에 관심 } \\
\text { 을 갖고 행동하는 세계시민을 양성하는 프로그램 }\end{array}$ & $\begin{array}{c}\text { 6개월 } \\
\text { (8월 ) }\end{array}$ & 15명 \\
\hline
\end{tabular}

출처: 국제개발협력민간협의회, "월드프렌즈 $\mathrm{NGO}$ 봉사단 사업안내서"

월드프렌즈 $\mathrm{NGO}$ 봉사단의 성과는 세 가지 측면으로 정리할 수 있다.

첫째, 지역밀착형 개발 협력으로 협력대상국 우호협력 및 복리증진에 기여한다는 점이다. 2016 년 기준 32 개국 80 개 단체 189 개 사업장으로 연간 327 명, 누적인원 3 천 명 규모 단원 파견, 교육, 보건, 농업, 지역개발 등 다양한 분야에서 활동함으로써 봉사단 파견을 통한 지식 과 기술의 나눔을 가능하게 한다. 공모전 실행을 통한 지역사회 발전 기여 및 사업효과 확대의 측면도 있다. 프로젝트 공모전의 경우 프로젝트 수요 조사에서 실행, 평가까지 프로젝트 단계 별 과정을 경험함으로써 파견단체 활동에 기여하는 것은 물론, 단원의 성장 및 국제 개발 전문가로 성장할 수 있는 기회를 제공한다. 그리고 탐방 공모전을 통한 국가 및 지역사회 문제 해결과 시민사회 발전을 위해 노력하는 국제기구, 국제 및 로컬 NGO 방문으로 활동국가 내에서 다른 비전과 목적을 가지고 활동하는 단체를 이해하고, 협력관계 구축의 가능성을 찾을 수도 있다.

둘째, 앞에서도 기술한 바 있지만, 국제 개발 협력 $\mathrm{NGO}$ 의 인적 기반 및 현지 역량 강화에 기여한다. 개발 협력 분야에 관심이 있거나 진출을 희망하는 이들을 대상으로 개발 협력 현장 경험과 사업 수행 기회를 제공함으로써 해당 분야 잠재적 인력 기반을 확대한다. 그리고 보건, 교육, 농림수산, 공공행정 분야 등 전문가를 ‘프로그램 매니저(PM)'로 파견함으로써 지역 조사, 
사업기획 및 실행, 평가 등 현장 사업 전반의 전문성 향상에 기여한다. '코디네이터' 또한 정보 공유, 교육 등 현지에서 $\mathrm{NGO}$ 의 효과적인 사업 수행을 위한 기반을 마련하는 역할을 한다. 코디네이터 파견국을 중심으로 다양한 현지교육 프로그램을 실시함으로써 현지 활동 역량을 강화하고, 현지의 다양한 활동 주체들과의 협력적 네트워크 형성에 기여하는 등 개발 협력 현장의 전문성 향상에 기여하고 있다.

셋째, 현지 활동과 후속 프로그램을 통한 참가자 개인의 성장을 지원한다. 일반봉사단 활동 후 프로그램 매니저 또는 코디네이터로 활동하거나 파견단체의 실무자로 채용되어 본부 또는 지부에 근무하는 사례가 증가하고 있는 등 봉사단원 활동이 개발 협력 분야로 진출하는 관문이 되고 있다. 또한 과거 세계시민교육 강사 양성 중심의 귀국단원 프로그램에서 국제 개발 협력 이해교육, $\mathrm{PCM}$ 등 실무교육, 멘토링을 포함한 단계별 프로그램 구성을 통해 국제 개발 협력 분야 취업을 희망하는 귀국단원에게 도움이 되는 커리어 로드맵을 제시함으로써 지속적 활동 및 진로 설계를 지원한다.

\section{SDGs 달성을 위한 민간의 역할}

추가적으로, 월드프렌즈 $\mathrm{NGO}$ 봉사단은 SDGs 달성을 위한 민간의 역할을 충실히 수행하고 있다. 현지 밀착형 개발 협력 사업으로, 현지 삶 속으로 한층 가까이 들어가 활동하는 NGO봉사 단원의 활동 분야와 SDGs는 밀접한 연관성이 있다.

파견단체 주요 사업들과 SDGs의 높은 연계성도 월드프렌즈 NGO봉사단의 강점이다. 보건/ 의료, 교육, 환경, 사회적 기업, 지역개발, 주거 개선, 식수 개발, 농업 등 여러 분야에 걸쳐 특화된 $\mathrm{NGO}$ 들이 포진해 있다.

기동성과 유연성도 빼놓을 수 없다. 현지 상황을 신속하게 판단하고 현지에 필요한 사업 및 활동을 즉각적으로 검토, 실행할 수 있는 순발력이 강점이며, 변화하는 상황에 대한 유연한 대처가 가능하다는 점도 민간에게 기대할만한 부분이다. 
〈그림 3〉 월드프렌즈 NGO봉사단 활동과 SDGs

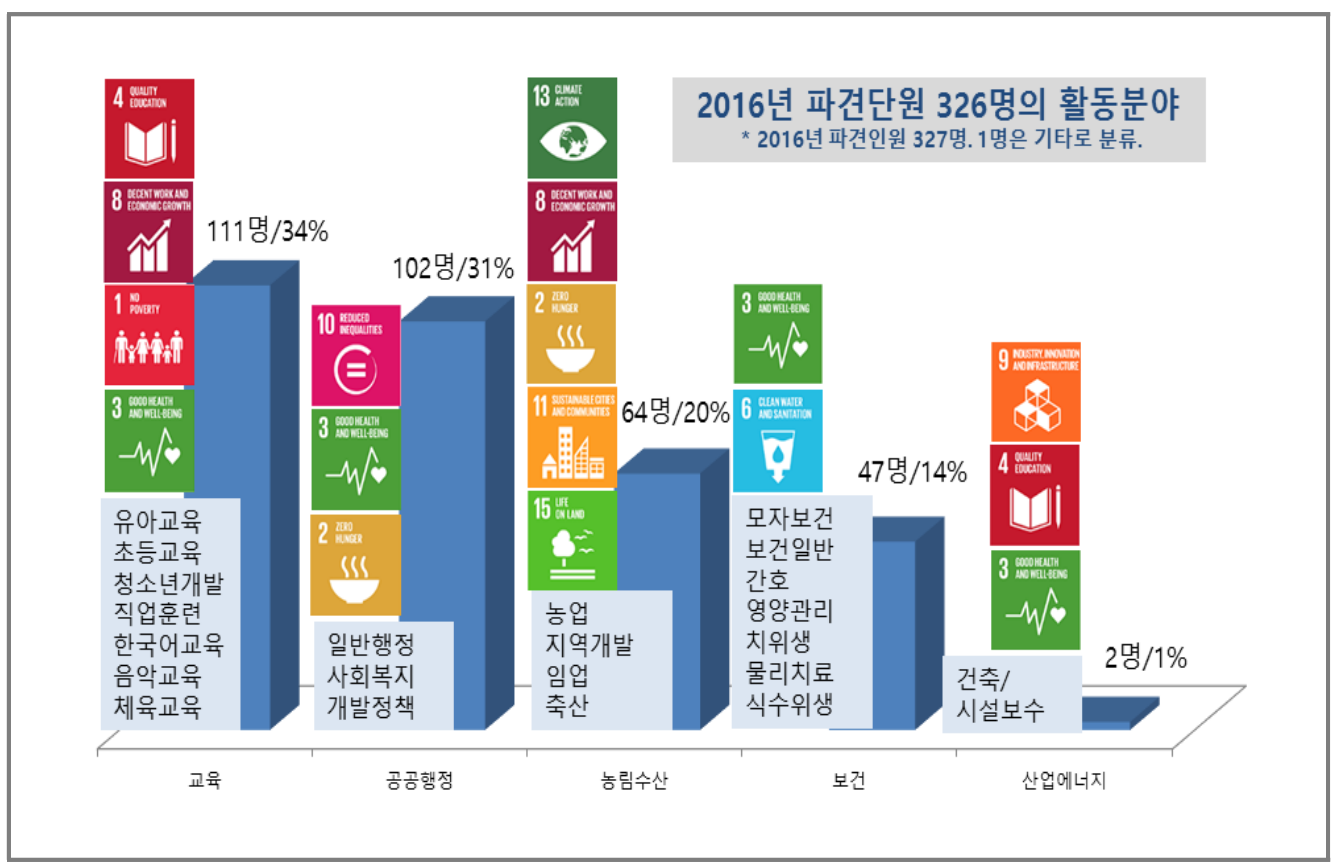

출처: 국제개발협력민간협의회, "월드프렌즈 NGO봉사단 통계"

\section{V. 한국 기업의 사회적 책임과 봉사단 활동}

$\mathrm{VSO}, \mathrm{CUSO}$ 의 경우에도 기업 연계 봉사단 프로그램이 확대되고 있는 것처럼 한국에서도 기업의 사회적 책임의식 증대와 함께 기업 해외봉사단 프로그램이 다양하게 운영되고 있다.

\section{1. 포스코 글로벌 청년 봉사단 '비욘드’}

포스코가 한국해비타트와 협력하여 운영하는 글로벌 청년 봉사단 '비욘드(Beyond)'는 현지 주민들을 위한 집짓기 봉사활동 및 재능 나눔을 수행하는 프로그램이다. 2007년 시작되어 매년 전국에서 100 명의 대학생들이 선발되어 1 년 동안 대한민국, 인도, 베트남, 태국, 인도네시아 등지에서 다양한 활동을 진행한다. 2011-2016년에는 포스그룹, 포스코1\%나눔재단, 현지 지방 정부, 해비타트가 협력한‘포스코 빌리지(POSCO Village)' 프로젝트를 통해 총 85세대가 거주 할 수 있는 집을 건립하기도 했다. 


\section{2. 기업과 시민사회의 협력 '라온아띠'}

$\mathrm{KB}$ 국민은행과 $\mathrm{YMCA}$ 가 협력하는 '라온아띠'는 지속가능한 지역사회, 지속가능한 아시아를 꿈꾸는 대학생 해외봉사단으로, 4명을 한 팀으로 구성하여 라오스, 미얀마, 베트남, 캄보디아, 필리핀 5 개국에 파견한다. 기간은 국내교육 1 개월, 현지 파견 5개월이다. 2008 년 시작되어 현재까지 467 명의 단원이 파견되었다.

라온아띠는 국제 개발 협력을 위한 기업(KB국민은행)과 시민사회(한국 $\mathrm{YMCA}$ )의 파트너 십 모델이라는 측면에서 의미가 있다. 또한 라온아띠는 아시아적 감수성을 가진 한국사회 청년 지도력을 키우고, 아시아 현지의 청년, 지역사회와의 파트너십 구축으로 주인의식과 상호책임의 식을 제고하는 참여형, 지역 밀착형 개발 협력 모델을 지향한다.

\section{제 I 장}

현대자동차그룹의 해피무브 글로벌 청년 봉사단은 2008년부터 매년 1천 명의 대학생을 봉사 단으로 선발, 방학기간을 이용해 해외로 파견하고 있다.

\section{VI. 결어}

MDGs와 다른 SDGs 특징 중 한 가지는 참여주체 측면이다. MDGs가 정부 중심이었다면 $\mathrm{SDGs}$ 는 정부뿐만 아니라 시민사회, 민간기업 등 모든 이해관계자의 참여를 기반으로 한다는 점이다. SDGs는 태생부터 시민사회의 다양한 목소리를 반영하여 설정되었고, 따라서 관련 주체 모두가 각자의 섹터에서 자신의 역할을 수행한다는 것이 전제다. 게다가 17 개의 목표 중 17 번은 아예 'Partnerships for the Goals'로 설정되어 있다. SDGs의 수많은 목표를 달성 하기 위해 무엇보다 협력이 중요함을 표명하는 것이다.

현장의 사업에 있어서도, 사업에 투입되는 인적 요소에 있어서도 각자의 강점에 기반한 협력을 통하면 더 풍성한 결과물을 얻을 수 있다고 본다. 해외봉사가 더 확장된 파트너십을 통해 더욱 알찬 성과를 얻을 수 있기를, 그래서 개발 협력의 결실이 더욱 커질 수 있기를 소망한다. 


\section{〈참고문헌〉}

한국국제협력단. 2016. 『한눈에 읽는 2015년 World Friends Korea 주요통계』. 성남: 한국국제협력단.

Peace Corps. 2015. "Performance and Accountability Report: FY 2015.” Washington, D.C.: Peace Corps, available at https://www.peacecorps.gov/about/opengovernment/reports/ (접속일: 2017.04.16)

UN. 1987. "Our Common Future, Chapter2: Towards Sustainable Development" (A/42/427). New York: UN.

_. 2015. "The Millennium Development Goals Report 2015.” New York: UN, available at http://www.un.org/millenniumgoals/news.shtml (접속일: 2017.04.16) VSO. 2016. "Annual Report and Financial Statement for the year ending 31 March 2016."London: VSO, available at https://www.vsointernational.org/ about-us/annual-report (접속일: 2017.04.16.)

미국 평화봉사단 홈페이지: http://www.peacecorps.gov (접속일: 2017.04.16) 시드글로벌헬스(Seed global Health) 홈페이지: http://seedglobalhealth.org/about (접속일 : 2017.04.16.)

VSO 홈페이지 https://www.vsointernational.org/volunteering (접속일 : 2017.04.16.) CUSO International 홈페이지: http://www.cusointernational.org/volunteer/typesof-volunteers (접속일 2017.04.16.)

JICA Volunteer Program: http://www.jica.go.jp/english/our_work/types_of_ assistance/citizen/volunteers.html (접속일: 2017.04.16)

$\mathrm{UN}$ 홈페이지: http://www.un.org (접속일: 2017.04.16)

Sustainable Development Knowledge Platform 홈페이지: https://sustainabledevel opment.un.org (접속일: 2017.04.16.) 